\title{
Undergraduates' Learning Achievement and Attitudes toward Learner Autonomy in a Fundamental English Course Incorporating Additional Facebook Group Activities
}

\author{
Paunluck Puntahachart Saengsawang
}

\begin{abstract}
This study examined 1) undergraduates' learning achievement in a fundamental English course that included activities with a Facebook group; 2) the level of students' attitudes toward learner autonomy; and 3) the level of their attitudes toward Facebook use in an English course. The subjects in the study were first-year undergraduate students that had registered for fundamental English course at King Monkut's University, North Bangkok (KMUTNB). They were selected using the convenience sampling method, and were organized into an experimental group. Students were provided with additional activities or homework with the Facebook group. The results indicated that the students' learning achievement was not in accordance with the efficiency criterion and the levels of their attitudes toward learner autonomy during the three phases studied were significantly different. However, the students' attitudes toward integrating Facebook into an English course were found to be positive.
\end{abstract}

Keywords: Learning achievement, Attitudes toward learner autonomy, Additional activities, Fundamental English Course, Facebook group

\section{Introduction}

The advance in technology has enhanced quality of life and convenience. It also supports learners in various ways in terms of learning and acquiring knowledge. Moreover, the use of social networking systems is growing rapidly and has become popular people use communicating tools, such as mobile phones, tablet PCs, and computers to send texts, to email, or communicate with each other and among groups. Technology surrounds us and changes quickly, which has led to new learning experiences (Bloch, 2008).

Social networking engages people in social interaction and communicating through social networking sites where they can share their profiles, information, or personal interests. This is related to certain important issues, such as "friendship" or "peer feedback" (Pempek, Yermolayeva, \& Calvert, 2009). Social networking technology is not only used for personal contact, but also for the purpose of business and education (Lane \& 
Coleman, 2011). With this technology, people communicate or send text messages and responses via chat rooms, blogs or message boards, and it has come to the attention of educators that these social networking technologies can be effective in teaching writing to students(Bloch, 2008). They are also offered opportunities to practice their writing skills on various other platforms, such as Googledocs, MySpace, and Facebook (Yancey, 2009). The usefulness of social networking tools is not solely limited to writing; they can also be utilized meaningfully with other skills.

One prominent social networking site is Facebook, which is the most popular compared to other sites and is registered most by users (Dave, 2012). As stated regarding the Facebook statistics (Facebook, 2013), over 650 million people around the world are daily active users, and approximately $79 \%$ reside outside the U.S. and Canada. In Thailand, there are more than 18 million users with $32.9 \%$ from the age group 18 to 24 (Checkfacebook, 2013). Users can create a profile page where they can share their information such as status, friends, photos, notes, groups, and wall posts. Moreover, groups can be created by users who would like to share similar hobbies or interests. Group applications can be public and available to everyone, or private. Those people who are invited to the group can join and view discussions or events. Establishing a group can also be beneficial for learning outside the classroom by using it as a communication tool between teacher and students to share useful links, files, photos and videos, supplementary lessons, and feedback. This application benefits the language classroom because it can create a meaningful and powerful learning community, and the students' experience with it encourages responsibility and progress in gaining and managing their knowledge (Garrison \& Kanuka, 2004). Thus, becoming a member of a group on Facebook can be an effective educational experience if it is integrated with the language classroom (Blattner \& Fiori, 2009). Munoz \& Towner (2009) suggested that instructors should encourage students to become involved in course activities on Facebook where they can communicate through wall posts or discussions, show useful links with course materials, such as video clips, websites, Power Points, assignments, tutorials, and create a meaningful learning community.

Because of these advantages and useful functions of Facebook, in this empirical study, the researcher investigated students' learning achievement and their attitudes toward learner autonomy in a fundamental English course that incorporated additional Facebook group activities. The study proposed the following research questions:

- Is the students' learning achievement in accordance with the efficiency criterion $E_{1} / E_{2}=80 /$ 80 (E1 = efficiency of the learning process / E2 = efficiency of learning outcomes)?

- What are the learners' attitudes toward learner autonomy?

What are the learners' attitudes toward in an English course? 
This experimental research was conducted to be a guideline for developing classroom instruction and for using appropriate technology to suit learners' needs and characteristics. Moreover, the study aimed to provide useful directions for promoting learners' positive attitudes and motivation toward English learning.

\section{Hypothesis}

The students' learning achievement is in accordance with the efficiency criterion $\left(\mathrm{E}_{1} / \mathrm{E}_{2}=80 / 80\right)$.

\section{Literature review}

\section{Facebook use in the context of learning English}

With mobile technologies these days, as viewed by Godwin-Jones (2008), social networking sites like Facebook, Twitter, or MySpace bring convenience to young people for "social interactions" and as means of communication that are beneficial for language learning. He also added that, with the function of language support on a mobile phone such as an iPhone, it would seem to represent a new language study tool that can "leverage the current student generation's heavy reliance on social networking in support of language learning."

Facebook use has been ubiquitous among university students and is beneficial for creating a knowledge base for teachers and students (Hew, 2011). Various studies have indicated the advantages of Facebook. For example, this social networking website has been harnessed for teaching and learning
English. It offers useful features for classroom teaching. In order to participate in the activities or group discussion, it is important to use English to communicate most of the time. This indicates that Facebook holds potential for students in the English learning context (Kabilan, Ahmad, \& Abidin, 2010). Utilizing Facebook in instructional practices is a good idea because it can lead to more student involvement and positive academic outcomes (Junco, 2012a). In other words, Facebook provides sources and space for learning, and connects the students' personal life and socializing with the academic environment (Yunus \& Salehi, 2012).

Blattner and Fiori (2009) have pointed out that Facebook is able to create authentic language interaction or a community for language classrooms where the learners' socio-pragmatic competence can be developed. It is a tool which can "enhance the sense of belonging" and has "unique features that offer constructive educational experiences while maintaining privacy and safety" (p.25). In addition, it can be used to motivate and improve the performance of language learners by providing various activities which focus on language contexts and communication practice. These activities can be offered on the group application on Facebook where students have opportunities to join easily and are able to communicate or discuss in the target language through wall posts, where their written expressions can be observed and on which feedback can be provided. The students can implement the comments or suggestions 
they receive in order to improve their language skills (Suthiwartnarueput \& Wasanasomsithi, 2012). However, the use of Facebook groups can have both positive and negative results in terms of their motivation(Yunus \& Salehi, 2012). Students can become demotivated with negative comments, while positive feedback can encourage their self-esteem and their desire to learn. As revealed by various studies on Facebook (Blattner \& Fiori, 2009; Haverback, 2009; Hurt et al., 2012; Kabilan, et al., 2010; Mills, 2009; Suthiwartnarueput \& Wasanasomsithi, 2012; Yunus \& Salehi, 2012), this social networking site seems to be an appropriate tool for an educational settings - it is able to blend learners' socialization and academic content, so that they can share knowledge, lessons, class materials, and sources of the content, and be motivated to learn the language.

\section{Attitude toward learner autonomy}

Holec (1981) defines learner autonomy as "the ability to take charge of one's own learning." Similarly, Dickenson (1987) describes autonomy as "complete responsibility for one's learning, carried out without the involvement of a teacher or pedagogic materials", and "a capacity to include an attitude to learning." In language education, autonomous learning has played an important role for language learners. Shujun \& Quian (2006) define autonomous learners' characteristics as taking charge of the learning process; for example, learners should be able to scope the aims, select the learning materials, and create their own progress and engage in their own evaluation. Stevens (2007) suggests that an autonomous learner depends not only on himself or herself - they can also learn through "a learning community" these days. The student should seek his or her own learning strategies related to the "network and community" and that might be effective in helping him or her to become autonomous and prepared for lifelong learning. Najeeb (2013) indicates the following basic principles of autonomy in language learning: students' involvement in the learning process, offering them opportunities to be responsible and to evaluate their learning, and use of the target language in the learning context. She also supported the idea that students learn better in a comfortable learning environment; therefore, they tend to develop their own learning strategies, do not hesitate to ask questions or for teacher's help, and are able to select materials for self-study. Once they gain confidence, they can manage their own learning process, and this will bring about an awareness of achievement.

An attitude, according to Oroujlou and Vahedi (2011), is defined as "a set of beliefs", for example, about a subject, a teacher, or a culture. One's attitude can lead to motivation or a reason for doing something. Smith (1971) states that an attitude, which can be defined as beliefs toward something, comes about within a situation and lasts for a long time. He also adds that one's attitude is a key factor in achieving goals within a given situation. One can be or not be successful with his or her learning due to positive or negative attitudes, which are important influences in terms of perceiving and responding to what is learned. For example, in studying a

$118 \quad$ Journal of NELTA, Vol 18 No. 1-2, $\quad$ December 2013 
foreign language, a learner with neutral or positive attitudes will possibly have a better opportunity to learn the language because of his or her open-mindedness and enthusiasm. Within the context of learning, a student that dislikes his or her school, teachers, or homework, for example, can quickly find the classroom unpleasant and be unwilling to learn or participate.

Attitudes are important in the languagelearning context as indicated by Shujun and Quian (2006) when they argue that “...attitudes and ability are the core of learner autonomy in language learning" (p.68). Therefore, to develop and succeed in terms of learner autonomy, learners need positive attitudes, knowledge, and skills. They also conclude that "autonomous learners should possess both the attitudes of willingness toward language learning, and the ability of taking charge of their own learning" (p.68). In addition to applying creative pedagogical methods or technologies to the classroom or to a situation, the inner factors of learners are also vital for them to learn, acquire knowledge, and achieve their goals. Therefore, use of appropriate methods in the class, learners' participation, and instructional processes and media can create more positive attitudes, which in turn will lead to success in the learning situation.

\section{Related studies}

\section{Facebook-related studies}

Various studies on Facebook in language learning situations have been conducted and several of them have revealed positive results regarding engagement with this social networking site in their research. Mills (2009), for example, studied the usability of Facebook in learning the French language. Facebook use was found to be a valuable environment to experience, which was timely and culturally relevant to her students. She discovered that her students - with the help of Facebook as an authentic environment for enhancing communication, interaction and discussions in French - were able to meet the grammatical, functional and linguistic objectives of her French language course. In addition, Haverback (2009) observed and examined that her students in a reading course created and participated in a Facebook group to discuss assignments, ask and answer questions, post information, and support one another for their educational courses. The students were found to be motivated to participate in "discussions on Facebook and they gained a better understanding of the theoretical principles in ensuring effective reading and developed better ideas as a group compared to when they read individually." The writer suggests that this technology and social networking websites offer an "educational community" which not only allows contact between teachers and students, but also provides them with learning opportunities.

Another research reported positive results on English grammar and writing skills (Suthiwartnarueput \& Wasanasomsithi, 2012). In this study, the subjects were allowed to discuss grammatical structures or points and explanations about writing by posting 
them on a Facebook group. The findings resulted from the analysis of the mean scores of the pre-test and post-test revealed that their English grammar was improved and they had positive attitudes toward the site as a tool for studying grammar and writing. Learners felt that the Facebook group helped their writing by providing them with opportunities to brainstorm and acquire new vocabulary (Yunus \& Salehi, 2012). This is congruent with a study of Shih (2011), which blended use of Facebook in a writing class. The students were given opportunities to post their writing assignments on Facebook, which were then assessed by other members of the group as peer feedback. The results showed that integrating this method in writing instruction was effective and that the students' writing skills improved, including positive attitudes and motivation to participate in class. Moreover, Facebook enables the students to socialize with friends and others, including applying sources of information and developing their thinking skills (Al-Shehri, 2011). Students are offered more comfort and convenience, familiarity, and ease of use, which may enhance their learning community on Facebook compared to other web-based discussion tools (Hurt, et al., 2012; Roblyer, McDaniel, Webb, Herman, \& Witty, 2010).

Furthermore, the study conducted by Kaliban, Ahmad \& Abidin (2010) suggested the feasibility and implications of Facebook in an English course; that is, Facebook facilitated and allowed students to participate in learning. However, they should pay more attention to target activities than the socialization function on the website so that the content can be learned meaningfully. Therefore, to integrate Facebook in the language-learning situation, teachers should have a certain learning platform that informs students of the clear objectives, learning outcomes, assessments, and the teacher's class management so that they can focus on learning content while using Facebook.

Meanwhile, a few studies have revealed negative effects of using Facebook. For example, Kirschner and Karpinski (2010) investigated the impact of Facebook on students' academic performance, and the results revealed that Facebook users spending fewer hours on studies reported a lower mean GPA than the nonusers, although their time spent on the Internet was not different. The Facebook users were reported to be engaged in more extracurricular activities related to social interactions or networks, such as group and clubs. The main finding showed a negative relationship between the Facebook users and their academic performance; that is, there may be a risk of conducting, as previously mentioned, two or more activities at the same time. In other words, implementing "two cognitive processes simultaneously" might affect one's tasks in a negative way.

Furthermore, other studies have reported a negative relationships among academic outcomes, multitasking, and time spent on class (Junco, 2012b; 2012c; Junco \& Cotten, 2012). Junco $(2012 b)$, for example, examined the 
relationship between Facebook use and academic performance by gathering data through a survey on 1839 students. The results showed that there was a negative relationship between the time spent on Facebook/checking Facebook and overall GPA. The researcher also concluded that, besides examining their use of Facebook, there might be other extraneous variables that affect academic outcomes, such as their ability to manage time and the various activities done on the site. Later research (Junco \& Cotten, 2012) studied the effects of multitasking on academic achievement, which were related to how students used Information and Communication Technologies (ICTs) or the Internet while doing schoolwork. The results revealed that multitasking using Facebook and text messaging was a negative predictor of students' overall GPA. The causal inference could be that both tasks are rather related to social purposes than academic ones. Hence, these ICT activities could impact academic outcomes because doing them may cause students to experience overloads in their study process. Another study (Junco, 2012c) confirmed these results by examining students' multitasking or activities done during class and their academic achievement. Using Facebook and text messaging was found to be the most frequent activity that was negatively predictive of overall GPA.

As seen in these Facebook studies, this site can be utilized in classroom instruction or academic courses. However, the results were found to be both positive and negative in educational situations. Facebook may not be a major cause of those outcomes, however, since other variables, such as gender, personality, attitudes, motivation, types of activity, contents, and time management, may also have played an important role for the results.

\section{Related research on attitudes toward learner autonomy}

Some studies on the attitudes toward learner autonomy have revealed interesting results. Wisaijorn and Tremayne (2008), for example, studied Thai university students' attitudes toward learner autonomy and selfdirected learning, and the results revealed that they had high agreement in making their own decision about selecting contents and managing the learning process. However, the results also showed a contrast; that is, the students viewed teacher-dependence necessary when they were involved in grammar and vocabulary activities or some difficult tasks in which they might need some explanations or clarifications from the teacher.

In the same way, Shujun and Qian's (2006) research on students' attitudes toward learner autonomy found that, in the questionnaire section of the "students' willingness to take responsibility," they were seen to possess positive attitudes and agreed highly with taking charge of their own learning. However, they viewed that teachers still played important roles because they tended to follow the teachers' instruction, explanation, and learning management.

Additionally, Breeze (2002) studied Spanish university students' attitudes toward learner autonomy, and the 
results revealed that they generally agreed with the idea of taking responsibility for their own learning, independent, and project-based work. They also felt confident about their problem-solving skills and they viewed that external assessment was not the main factor in motivating them to be self-directed. Although their attitudes were prone to be positive toward autonomy, most of them were indecisive about what was to be learnt and how. They still were dependent on the teacher; that is, they thought that the teacher was responsible for the class materials or content and for correcting homework.

As revealed in these studies, the students realized the importance of learner autonomy, and viewed that it was vital for their study and academic achievement. Nevertheless, to some extent, they still were teacherdependent and required the teacher's assistance in guiding them through learning situations. In conclusion, to achieve learning goals and to yield lifelong learning, it is necessary for students to build up their sense of autonomous learning, which will allow them to be self-directed and gain selfaccess learning skills in the future.

\section{Methods}

\section{Participants}

This experimental research was of onegroup design. The population of the study was first-year undergraduate course students $(N=3,659)$ registered to a fundamental English course during the first semester, which lasted four months. The sample size of 161 students was obtained through a convenience sampling method because they belonged to the researcher's registered course sections.

\section{Research instruments}

\section{Questionnaires}

Three questionnaires were employed in this study to obtain the sample's personal data, attitudes toward learner autonomy, and attitudes toward their use of Facebook. The first survey was conducted to investigate the demographic characteristics of the sample. Questions included such issues as gender, age, duration of learning English, computer skills, frequency of the Internet use, and problems in learning English and weak skills. Secondly, a 5-point Likert scale questionnaire was employed to survey the sample's attitudes toward learner autonomy, which was conducted in three phases: pre-, mid-, and postcourse survey. The issues in the survey included three aspects: cognitive, affective, and psychomotor domains. They were, for example, "I keep a record of my study, such as keeping a diary, writing reviews, etc.," "I can learn without the teacher's supervision," and "The teacher should only be a counselor, a helper and a guide." Thirdly, additional 5-point Likert scale questionnaires about their attitudes toward their Facebook use were distributed at the end of the semester. The issues here were, for instance, "You view that social networking technology is necessary for learning English," "You are satisfied with receiving notifications when messages or things are posted on the group's wall," "You are willing to do the 
activities on Facebook provided by the teacher," and "Participating in the group on Facebook allows you to be more creative."

\section{Facebook group}

In the experimental part of the present study, the sample was provided with the normal process of in-class instruction for 15 weeks and they were assigned to do additional activities or homework every week with the Facebook group, set up by the teacher. Students could do the tasks and activities during classroom breaks or outside the classroom. The contents of additional activities were based on lessons from a course book named Global:Pre-intermediate Textbook (Clandfield, 2010). The assignments were, for example, "Write at least five sentences about your hopes and plans for the future by using the structures of hope/ plan/ would like/ want/ looking forward to," "Make 6 sentences about rules or regulations in a place (e.g. at school, university, library, hospital, museum, on the bus, etc.) by using have to, don't have to, can, can't, must, and mustn't for each sentence," and "Vote for or add more good things for what you did for your mother on Mother's Day," Students were required to send or post their assignments or homework on the group wall and they received feedback from the teacher. With the Facebook group, they were required to communicate in English most of the time. The Facebook group was also used as a tool to share opinions, information, or useful links about the English lessons between the teacher and students. The teacher also provided learning resources in PDF format and PowerPoint slides.

\section{Formative and summative assessments}

According to Garrison and Ehringhaus (2007), formative assessment can be partly incorporated in an instructional process and is similar to "practice," which includes such factors as obvious criteria and goal setting, class observations, teacher's questioning, selfand peer assessment, and students' record keeping. Summative assessment is used as an important part of a course, such as end-of-unit tests, end-of-term or semester exams, and grade reports. In this study, during the semester, the sample was provided with formative assessments which included worksheets, the teacher's feedback, and observations. Then, in the middle and at the end of the semester, summative tests (semester exams) were administered. Before both assessments were provided, the objectives and test specifications were set.The contents of worksheets and tests were examined by academic specialists using the Item Objective Congruence index (IOC).

\section{Interview}

At the end of the semester, a semistructured interview was conducted. Twelve participants were randomly selected in order to gain in-depth information about their attitudes toward learner autonomy and Facebook use. They were asked questions such as "How can you improve your English language skills?", "To what extent do you think doing assignments or homework on the Facebook group is effective?," and "To what extent do you think autonomous learning can help or play an important part in studying English?" The interview process lasted approximately 15-20 
minutes and was conducted in Thai, their native language.

\section{Analyses}

Descriptive statistics, mean, and S.D. were used to analyze the sample's personal data and attitudes toward learner autonomy and Facebook use. Furthermore, the efficiency index (E1/ E2) was used to analyze the efficiency of the instructional process incorporated by doing additional tasks with the Facebook group. In this study, the students' learning achievement was analyzed from the formative and summative assessments in order to determine if it was in accordance with the specified criterion. The criterion was set at a $80 / 80$ basis, as it is the standard used generally for instructional processes in a language course where the content pertains to knowledge, memorizing, and understanding (Nuangpirom, 2011).

$\mathrm{E} 1$ is defined as the percentage of the mean scores derived from doing activities through an instructional process or package (efficiency of the learning process). E2 means the percentage of mean scores generated by taking a test after the learning process (efficiency of learning outcomes). The efficiency index can be calculated from the following formula (Yamkasikorn, 2008).

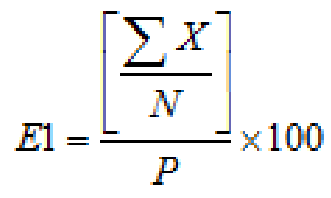

E1 $=$ efficiency of the learning process
$\Sigma X=$ sum of mean scores derived from doing activities during the instructional process

$\mathrm{N}=$ numbers of learners in the instructional process or package

$\mathrm{P}=$ total scores of doing activities during the instructional process

$$
E 2=\frac{\left[\frac{\sum Y}{N}\right]}{O} \times 100
$$

E2 = efficiency of learning outcomes

$\Sigma \mathrm{Y}=$ sum of mean scores derived from taking summative tests after the instructional process

$\mathrm{N}=$ numbers of learners in the instructional process or package

$\mathrm{O}=$ total scores on the summative test

\section{Results and discussion}

\section{Respondents' personal data}

The sample consisted of males and females, at $47.2 \%$ and $52.8 \%$, respectively, aged between 18-20 years. They had been studying English for 1314 years on average. Moreover, the sample had fair computer skills with regular computer and Internet use, and most of them used social networking websites. The respondents sometimes had an opportunity to use English outside the classroom; for example, they used English on the Internet, while playing games, with friends or foreigners, on trips, and at temples/ churches/school. However, most of them had problems using vocabulary and grammar. In studying English, they 
expected to improve or be able to apply their English skills, and to gain more vocabulary and grammar knowledge.

\section{Learning achievement}

Table 1: Descriptive statistics of formative and summative test scores

\begin{tabular}{lcccccc}
\hline Scores & N & Total & Min. & Max. & Mean & S.D. \\
\hline Formativeassessments & 161 & 100 & 31.00 & 89.00 & 60.37 & 12.39 \\
\hline Summativeassessments & 161 & 70 & 22.59 & 64.91 & 43.67 & 9.89 \\
\hline
\end{tabular}

Table 1 shows the descriptive statistics of the students' scores, which were derived from the formative and summative assessments with mean scores at $60.37($ S.D. $=12.39)$ and 43.67 $(S . D .=9.89)$, respectively.

Table 2: Efficiency index of the instructional process incorporating additional activities into the Facebook group work

$\begin{array}{cccccc}N & A & \text { “X } & \text { B } & \text { “F } & \text { E1/E2 } \\ 161 & 70 & 9719 & 100 & 7030.67 & 60.37 / 62.38\end{array}$

$\mathrm{E}=$ Scores obtained from formative assessments

E2 $=$ Scores obtained from summative assessments

Table 2 shows the efficiency of the instructional process that incorporated additional tasks or homework with the Facebook group. The criterion was set atE1 $/ \mathrm{E} 2=80 / 80$. The results revealed that the students' learning achievement was not in accordance with the specified criterion - that is, it was lower than 80 and was rated at E1/E2 $=60.37 / 62.38$.
In answering research question 1, "Is the students' learning achievement in accordance with the efficiency criterion $E_{1} / E_{2}=80 / 80$ ?," as shown in the results, the students' learning achievement was not in accordance with the efficiency criterion; the result rejected the hypothesized statement. This was incongruent with the reviewed studies, which revealed positive results of using Facebook (Suthiwartnarueput \& Wasanasomsithi, 2012; Yunus \& Salehi, 2012; Shih, 2011; Al-Shehri, 2011). The different outcomes may have occurred because the students in this study were only responsible for the tasks assigned by the teacher each week. They posted their work on the group wall, and it was checked and feedback from the teacher and friends was provided and they could view each other's work. In the present study, friends did not provide the same kind of feedback as the teacher did -they just made some comments or compliments which were not related to grammar or structures. In other studies, the students corrected each other's work on Facebook, and as a result, they were able to learn from the feedback from their friends. However, the results from this study were similar to previous studies on Facebook and academic performance. It has indicated that the use of Facebook during academic work had negative results on the students' overall GPA because the students tend to be attracted to the various functions of Facebook, such as games, socializing with friends, and news feeds(Kirschner \& Karpinski, 2010; Junco, 2012b; Junco, 2012c; Junco \& Cotton, 2012). For this 
reason, they might not be able to pay attention to their academic work. That is, students' regular Facebook use might cause them procrastination, improper time management, and distraction from their important academic work. In addition to using Facebook to do the additional tasks, they possibly implemented it for socializing and entertainment. Hence, being engaged in several tasks simultaneously can affect their study or learning achievement in a negative way (Kirschner \& Karpinski, 2010). Additionally,

there might be some other extraneous variables that

\begin{tabular}{|c|c|c|c|c|c|c|c|}
\hline \multirow{2}{*}{$\begin{array}{c}\begin{array}{c}\text { Data collection } \\
\text { (Phases) }\end{array} \\
\end{array}$} & \multicolumn{2}{|c|}{1 (pre-course) } & \multicolumn{2}{|c|}{2 (mid-course) } & \multicolumn{2}{|c|}{3 (post-course) } & \multirow{2}{*}{ Sig. } \\
\hline & Mean & S.D. & Mean & S.D. & Mean & S.D. & \\
\hline Learner Autonomy & 3.26 & 0.32 & 3.13 & 0.36 & 3.09 & 0.25 & .007 \\
\hline
\end{tabular}
affected their academic achievement, such as their academic majors (i.e. engineering, applied science, and technical education), background knowledge of the language, and the time spent on class work. Moreover, according to the researcher's records of students' taskparticipation, not all of the students participated in additional Facebook activities, but on average approximately $83 \%$ of them did. Their participation was found to be decreasing during the end of semester, at around $73 \%$, probably due to their workloads in other courses, which were usually full and due around that time. Consequently, other factors such as willingness to participate in doing assignments and responsibility seemed to play an important role in their following the additional activities on Facebook.

\section{Attitudes toward learner autonomy}

After gathering the questionnaires from the sample, they were analyzed according tomean and S.D. Then the data were interpreted according to these levels: strongly disagree $=1.00-1.80$ (lowest), disagree $=1.81-2.60$ (low), moderate $=2.61-3.40$ (medium), agree $=3.41-4.20$ (high), strongly agree $=4.21$ -5.00 (very high).

Table 3: Attitudes toward learner autonomy
Table 3 shows the mean scores and S.D. of the overall results of the attitudes toward autonomous learning. The questionnaires were distributed at three times: pre-, mid- and post-course. The mean scores of their attitudes were rated at 3.26, 3.13 and 3.09, respectively. These were found to be at a moderate level, with a statistically-significant difference. Moreover, the items with medium mean scores were, for example, "I make good use of my free time in English study," "I select the exercises to practice the language points I want to improve, and "The teacher should only be a counselor, a helper, and a guide." The results with high scores were, for example, "I find that I can finish my tasks in time," "I feel motivated to self-access and enhance knowledge," and "I prefer to read books, magazines, newspapers all by myself without the teacher telling me what to read." 
Table 4: Post Hoc Tests: attitudes toward learner autonomy

\begin{tabular}{lccc}
\hline Phases & 2 (Mid-course) & 3 (Post-course) & Mean \\
\hline $\mathbf{1}$ (Pre-course) & .014 & .022 & 3.28 \\
\hline $\mathbf{2}$ (Mid-course) & .985 & 3.13 \\
\hline $\mathbf{3}$ (Post-course) & & 3.14 \\
\hline
\end{tabular}

$p \geq .05$

Regarding research question 2, "What are the learners' attitudes toward learner autonomy?," the students' attitudes during all phases were found to be at a medium level. As can be seen in most issues in the pre-course questionnaire, the students seemed to be positive and confident about learning autonomously, for example in relation to such aspects as knowing their potentials, selecting their own materials, having the teacher as a helper, and planning their study (Breeze, 2002; Shujun \& Quian, 2006; Wisaijorn \& Tremayne, 2008). However, the mean scores of those issues in the mid-and post-course survey slightly decreased. When analyzed by Post Hoc Tests, it was revealed that phases 2 and 3 were not statistically or significantly different (.985) at the.05 level. On the contrary, they were statistically and significantly different from phase 1 (.14 and .02, respectively). As can be seen in Table 4 , in each phase, the mean scores were, starting from phase 1, 2 and 3, rated at $3.27,3.13$ and 3.14 , respectively. It can be inferred that the teacher's control over the learners' assignments or activities affected their attitudes toward learner autonomy. With every-week's assignments, students were required to follow and receive feedback, and this can be a key to the slightly decreasing attitude level regarding autonomous learning in phases 2 and 3. It can also be inferred that, with the teacher's control over each-week's assignments, they might have become more teacherdependent and exhausted with doing every task throughout the semester. In other words, they became more teacher-dependent with the provided activities, instead of being more autonomous. Furthermore, the assignments may have provided the students with too great a workload, so this could have created a slow followup time for every activity. More importantly, administering the same questionnaires three times may have led to exhaustion, which could have caused inaccurate self-report results. Therefore, the suggestion can be made that the data collection during two phases, pre and post, of the questionnaire was sufficient. Moreover, the students should have been offered more opportunities to select their own tasks and been allowed to do fewer additional tasks so that they could take a break from their workload, which may have caused them to have negative attitudes. 


\section{Attitudes toward Facebook use in an English course}

Table 5: Attitudes toward satisfaction of Facebook use

\begin{tabular}{c|c|c}
\hline \multirow{2}{*}{$\begin{array}{c}\text { Satisfaction of the } \\
\text { Facebook Use }\end{array}$} & Mean & S.D. \\
\cline { 2 - 3 } & 3.80 & 0.98 \\
\hline
\end{tabular}

Table 5 shows the respondents' attitudes toward their satisfaction with Facebook use in the course. The mean score was found to be at a high level, at 3.80, which meant that they were satisfied with using Facebook in the English course. Moreover, some of the items concerning their attitudes were all at a high level. Students were generally satisfied with utilizing Facebook in an English course because of its convenience in contacting friends and the teacher and because of its ease of use. They also had a positive view of the group function because they were able to follow the course materials and post-queries about the lessons. Furthermore, they viewed that participating in the group allowed them to take responsibility for their study and to be more interested in the course.

Regarding the research question 3, "What are the learners' attitudes toward the Facebook use?" the overall results showed that the students were very satisfied with using Facebook in their English course or in other academic courses. With the group function on Facebook, students are offered a meaningfully academic platform with which they can follow the course materials, contact classmates and the instructor conveniently, post comments and queries, send their assignments, and receive immediate feedback from the teacher (Blattner \& Fiori, 2009; Suthiwartnarueput \& Wasanasomsithi, 2012). Moreover, Facebook gave them a positive view concerning its implementation in classroom work because of its convenience (Roblyer, et al., 2010). They viewed that this platform was possibly suitable for an English course and could be applied in other courses due to its useful functions, it is free of charge, has a large number of users, and provides prompt notifications.

\section{Conclusion and implications}

This study investigated students' learning achievement and attitudes toward learner autonomy in a fundamental English course incorporated by additional activities with a Facebook group. The instruments used in the study were the Facebook group, formative and summative assessments, and questionnaires. The data were analyzed using descriptive statistics and efficiency index. The results revealed that the students' learning achievement did not correspond with the efficiency criterion. The causal inference can be drawn that students were only required to be responsible for the tasks assigned by the teacher each week. When they posted their work on the group wall, feedback was provided by the teacher, and friends did not provide the same kind of feedback as the teacher did they just made some comments or compliments which were not related to grammar or structure. As a result, they may have had a chance to learn only from the teacher and not exactly from the peer assessments, which might be a

$128 \quad$ Journal of NELTA, Vol 18 No. 1-2, December 2013 
beneficial method of language learning and learning about their mistakes. Additionally, other variables might have had effects on their learning achievement, such as their academic majors (i.e. engineering, applied science, and technical education), their language background knowledge, their time spent on class work, and the class workloads in other courses. Moreover, other factors such as the willingness to participate in assignments and responsibility seemed to play an important role in their following the additional activities on Facebook.

Regarding their attitudes toward learner autonomy and Facebook use, although they were positive about Facebook use in an English course, their attitudes toward learner autonomy seemed to improve in phases 2 and 3 , where the results were statistically and significantly different from the precourse results. It can be inferred that the teacher's control over the weekly assignments might have affected their attitudes toward learner autonomy. They might have become more teacherdependent and exhausted in doing the tasks every week throughout the semester. Furthermore, administering the same questionnaires three times may have led to exhaustion, which could have caused inaccurate self-report results. Therefore, the suggestion can be made that data collection during only two phases, pre and post, would have been sufficient. Also, the students should be offered more opportunities to select their own tasks and be allowed to do fewer additional tasks so that they can take a break, as too much of a workload may cause them to have negative attitudes.
Although the revealed results from integrating Facebook in an English course were seen to have negative effects on academic performance and attitudes toward learner autonomy, its platform and group functions can be applied in academic courses, especially in English courses. Due to its current beneficial functions, such as wall posts for messages, videos, photos, and files, it can be implemented appropriately in an academic course, especially for creating additional out-of-class activities, such as discussions, assignments, polls, notifications of events such as exam dates and so forth, and sharing ideas, information, as well as course materials. However, clear goals, objectives, and the evaluation of tasks need to be specified for the learners. In other words, when outlining the course contents, additional assignments are needed to correspond with each unit's theme. In addition to setting up meaningful tasks with objectives and evaluations, due to certain characteristics of Thai students, providing reinforcement as extra marks in the course evaluation criteria could arouse them to willingly participate in learning activities.

\section{Recommendations for future research}

For future research, to examine whether attitudes toward learner autonomy are related to the assessment results, it is recommended that a regression analysis between the attitudes and formative or summative scores be investigated. Another suggestion can be made that, in order to study other factors which may affect students' attitudes, activities inside 
and outside the classroom can be explored and their relationship with learners' attitudes toward learner autonomy analyzed. Finally, in the future, more types of technological use can be studied in order to investigate appropriate ways to promote self-access and autonomous learning, especially for Thai learners at tertiary levels.

\section{Limitations}

Some limitations exist in this study. First, the information from this study was descriptive and cross-sectional; therefore, apart from the instructional process and Facebook group activities, there may have been other causal mechanisms that determined what actually affected the students' learning achievement. Secondly, the students' three phases of responding to the questionnaire concerning their attitudes toward learner autonomy may have caused them exhaustion in reporting their attitudes. Therefore, it might have been better to have had them respond to the questionnaire only twice, before and after the course. Finally, due to the sample being drawn from a population of students at a single, public university, generalizations to students at other contexts and institutions may not be valid. Despite these possible limitations, some implications and methods from this study can be applied for academic courses, or other educational settings that share similar characteristics, as discussed above.

\section{About the author}

Paunluck Puntahachart Saengsawang is a Lecturer at Faculty of Applied Arts, King Mongkut's University of Technology
North Bangkok. She teaches English to undergraduates majoring in science and technology. Her fields of research are English language teaching and assessment, and using technology for education. Currently, her interests revolve around promoting learner autonomy and lifelong learning.

\section{References}

Al-Shehri, S. (2011). Connectivism: A new pathway for theorizing and promoting mobile language learning. International Journal of Innovation and Leadership on the Teaching of Humanities, 1(2), 10-31.

Blattner, G., \& Fiori, M. (2009). Facebook in the language classroom: Promises and possibilities. International Journal of Instructional Technology and Distance Learning, 6(1).

Bloch, J. (2008). From the special issue editor. Language Learning $\mathcal{E}$ Technology, 12(2).

Breeze, R. (2002). Attitudes towards learner autonomy among Spanish university students. Atlantis, 24(2), 23-36.

Checkfacebook. (2013). Facebook Statistics Retrieved May 8, 2013, from http:// www.checkfacebook.com/

Clandfield, L. (2010). Global: Preintermediate coursebook: Macmillan.

Dave, H. W. (2012). Global Social Media Statistics 2012, from http:// www.slideshare.net/TheHWD/ global-social-media-statistics-2012

Dickenson, L. (1987). Self-iInstruction in language learning. Cambridge: Cambridge University Press.

Facebook. (2013). Statistics Retrieved May 8, 2013, from http:// newsroom.fb.com/Key-Facts 
Garrison, C., \& Ehringhaus, M. (2007). Formative and summative assessments in the classroom, from http://www.amle.org/Publications/ WebExclusive/Assessment/tabid/ 1120/Default.aspx

Garrison, D. R., \& Kanuka, H. (2004). Blended learning: Uncovering its transformative potential in higher education. The Internet and Higher Education, 7(2), 95-105. doi: http:// d x.d o i . o r g / $10.1016 /$ j.iheduc.2004.02.001

Godwin-Jones, R. (2008). Emerging technologies mobile-computing trends: Lighter, faster, smarter. Language Learning \& Technology, 12(3), 3-9.

Haverback, H. R. (2009). Facebook: Uncharted territory in a reading education classroom. Reading Today, 27(2), 34.

Hew, K. F. (2011). Students' and teachers' use of Facebook. Computers in Human Behavior, 27(2), 662-676. doi: http:// dx.doi.org/10.1016/j.chb.2010.11.020

Holec, H. (1981). Autonomy and foreign language learning. Oxford: Pergamon.

Hurt, H. E., Moss, G. S., Bradley, C. L., Larson, L. R., Lovelace, M. D., \& Prevost, L. B. (2012). The 'Facebook' effect: College students' perceptions of online discussions in the age of social networking. International Journal for the Scholarship of Teaching and Learning, 5(2), 1-21.

Junco, R. (2012a). The relationship between frequency of Facebook use, participation in Facebook activities, and student engagement. Computers $\mathcal{E}$ Education, 58(1), 162-171. doi: 10.1016/ j.compedu.2011.08.004

Junco, R. (2012b). Too much face and not enough books: The relationship between multiple indices of Facebook use and academic performance. Computers in Human Behavior, 28(1), 187198. doi: 10.1016/j.chb.2011.08.026

Junco, R. (2012c). In-class multitasking and academic performance. Computers in Human Behavior, 28(6), 2236-2243. doi: http://dx.doi.org/10.1016/ j.chb.2012.06.031

Junco, R., \& Cotten, S. R. (2012). No A 4 U: The relationship between multitasking and academic performance. Computers \& Education, 59(2), 505-514. doi: http://dx.doi.org/10.1016/ j.compedu.2011.12.023

Kabilan, M. K., Ahmad, N., \& Abidin, M. J. Z. (2010). Facebook: An online environment for learning of English in institutions of higher education? The Internet and Higher Education, 13(4), 179-187. doi: 10.1016/ j.iheduc.2010.07.003

Kirschner, P. A., \& Karpinski, A. C. (2010). Facebook and academic performance. Computers in Human Behavior, 26(6), 1237-1245. doi: 10.1016/ j.chb.2010.03.024

Lane, M., \& Coleman, P. (2011). Technology ease of use through social networking media. Journal of Technology Research, 3.

Mills, N. A. (2009). Facebook and the use of social networking tools to enhance language learner motivation and engagement. NEALLT conference, Yale University. New Haven, CT.

Munoz, C. L., \& Towner, T. L. (2009). Opening Facebook: How to use Facebook in the college classroom. Paper presented at the Society for Information Technology and Teacher Education Conference, Charleston, South Carolina.

Najeeb, S. S. R. (2013). Learner autonomy in language learning. Procedia - Social and 
Behavioral Sciences, 70(0), 1238-1242. doi: http://dx.doi.org/10.1016/ j.sbspro.2013.01.183

Nuangpirom, P. (2011). Innovation and information technology for education Retrieved May 13, 2013, from http:/ / elecpnt.rmutl.ac.th/attachments / 121_12lesson7.pdf

Oroujlou, N., \& Vahedi, M. (2011). Motivation, attitude, and language learning. Procedia - Social and Behavioral Sciences, 29(0), 994-1000. doi: http:/ / dx.doi.org/10.1016/ j.sbspro.2011.11.333

Pempek, T. A., Yermolayeva, Y. A., \& Calvert, S. L. (2009). College students' social networking experiences on Facebook. Journal of Applied Developmental Psychology, 30(3), 227238. doi: 10.1016/ j.appdev.2008.12.010

Roblyer, M. D., McDaniel, M., Webb, M., Herman, J., \& Witty, J. V. (2010). Findings on Facebook in higher education: A comparison of college faculty and student uses and perceptions of social networking sites. The Internet and Higher Education, 13(3), 134-140. doi: 10.1016/ j.iheduc.2010.03.002

Shih, R. C. (2011). Can Web 2.0 technology assist college students in learning English writing? Integrating Facebook and peer assessment with blended learning. Australasian Journal of Educational Technology, 27(Special Issue 5), 829-845.

Shujun, Q., \& Quian, L. (2006). A survey on English majors attitudes towards learner autonomy. CELEA Journal, 29(5), 66-74.

Smith, A. N. (1971). The importance of attitude in foreign language learning. The Modern Language Journal, 55(2), 8288.
Stevens, V. (2007). The multiliterate autonomous learner: Teacher attitudes and the inculcation of strategies for lifelong learning. Independence 42 (IATEFL Learner Autonomy SIG), 27-28.

Suthiwartnarueput, T., \& Wasanasomsithi, P. (2012). Effects of using Facebook as a medium for discussions of English grammar and writing of lowIntermediate EFL students. Electronic Journal of Foreign Language Teaching, 9(2), 194-214.

Wisaijorn, P., \& Tremayne, B. (2008). Thai university students' attitudes to learner autonomy and self-directed learning. Journal of Humanities and Social Science, Kon Kaen University, 25(1), 92-115.

Yamkasikorn, M. (2008). How to use efficiency criterion in media research and development: E1/E2 and the 90/ 90 standard. Journal of Education, 19(1).

Yancey, K. B. (2009). Writing in the 21st Century. A report from the National Council of Teachers of English, 1-9.

Yunus, M. M., \& Salehi, H. (2012). The effectiveness of Facebook groups on teaching and improving writing: Students' perceptions. International Journal of Education and Information Technologies, 1(6), 87-96. 